\title{
Browsers and phone girls: the intricate socialities of friendship, trust and cyberlove in Nima (Accra)
}

\author{
Ann Cassiman
}

\begin{abstract}
Foreplay
Accra, 2 August 2014. I am sitting in one of the rooms of Hawa's house after a long day of hanging around in the neighbourhood. All of a sudden Hawa bursts into the room and points to the large Samsung smartphone she holds in her hand. The phone is on speaker and I hear a distant man's voice. As the conversation unfolds, Hawa first asks the man, in a friendly but desperate tone, to send her some money, before switching to a more dramatic register, crying out whether he still loves her. And if he does indeed still love her, why then did he not send the money as promised, she exclaims? The man - who, as I learn later on, is in the US - protests her questioning of his love and tries to explain to her that he has run out of money and that his friends are saying that all this is a scam. He sounds desperate as well, although his voice remains calm and composed. Hawa becomes angry: 'Why do you listen to these friends?!' And she shouts, apparently close to despair, 'Why do you hate me? I want to know what is on your mind. I don't know what to think anymore, so tell me everything is OK. I'm so worried, you know. I keep on crying all day.' At the other end of the line, the man mutters that she is freaking out.

When the conversation ends, Hawa looks at me with jeering eyes and bursts out laughing:
\end{abstract}

He's paying. Ooh yes, he's paying. He has already paid a lot kraaah! ${ }^{1}$ Every two weeks he has been paying, but this week he says, hmm, he has some bill to pay first. And you know, I was supposed to be at the airport, that was last week, but it wasn't real, it was set up. So he would have picked me up. But I wasn't there. It took him three days of holidays to come to the airport to meet me and I wasn't there.

Both of us sit on the ground in the small and warm windowless room. During her call, I had cautiously closed the door, although most people in the house were aware of her activities online as she had been making calls without being discreet.

This call and some earlier chats with Hawa sparked a new direction in my research in Nima, a popular neighbourhood in Accra, the capital of Ghana. ${ }^{2}$

\footnotetext{
Ann Cassiman is Associate Professor of Social and Cultural Anthropology at the Institute for Anthropological Research in Africa (IARA) of the University of Leuven. She is the author of the monograph Stirring Life: women's paths and places among the Kasena of northern Ghana (Uppsala University Press, 2006) and the editor of Architectures of Belonging: inhabiting worlds in rural West Africa (BAI Publishers, 2011). Her recent research focuses on friendship, gender, kinship and growing up in the zongos of Ghana. Email: Ann.Cassiman@soc.kuleuven.be

${ }^{1}$ Kraaah is a slang expression to emphasize what one has just said.

${ }^{2}$ Fieldwork was carried out in Nima in two periods: from June to August 2014 and in April 2015.
}

(C) International African Institute 2018 
I had been working with groups of young men and women on friendship, connectivity, futures and dreams, and the topic of scams ${ }^{3}$ and cyber fraud was omnipresent in many of our conversations.

Founded in the 1930 s by Muslim traders as a temporary settlement - called a zongo $^{4}$ in Hausa - today Nima is a bustling area that is densely populated, mainly by Muslim migrants from the northern regions of Ghana and more distant parts of West Africa such as Burkina Faso, Togo, Mali and Senegal (Harvey and Brand 1974).

Its ongoing attraction as a first arrival stopover - due to its central position in the capital, its affordable housing and the multiple transnational webs and networks that connect Nima to a broader world across West Africa and beyond makes it a node of intense mobility that keeps growing at a fast pace. Today, Nima is under high spatial pressure (Agyei-Mensah and Owusu 2012). As Nima is situated within the historic confines of the city of Accra and is closely surrounded by other, often newer, dense neighbourhoods, there is hardly any space for it to grow and expand. People share rooms with parents and children, with other close and more distant kin, with friends, and with friends of friends. The official unemployment rate in Nima is one of the highest in Ghana. ${ }^{5}$ Many men and women have no regular source of income and many parents do not know how to feed their children on a daily basis. Youth are very creative in finding ways to physically and virtually escape the harsh living conditions in Nima.

In this article I look into the specificities that characterize the 'art of being global' (Roy and Ong 2011) evident in Nima's youth in very specific local forms of 'friendship'. In a community such as Nima that is predominantly constituted by people with a migratory history, kinship has been complemented, and even partially replaced, by alternative forms and new layers of relatedness, composed using vocabularies and practices of friendship. And this new 'relatedness' is mainly defined geographically, through daily interactions that are shaped around relations of proximity and age. Starting from an analysis of real-time friendship in the zongo, the article follows a particular group of boys and girls - so-called browsers - who engage in online friendships and cyberlove relations with men abroad, not only as a means to make quick and easy money, but also as a form of 'worlding' (Simone 2001), referring to ways in which the city allows 'spaces of incapacity and marginality' to reach a larger world (ibid.: 23). I show how the modalities and intricacies of online friendship and love rely on vital localized bonds of (real-time) friendship of browsers and girls in the zongo, and how they affect these bonds in various ways that generate new possibilities but also erode some of the existing moral socialities between friends.

\footnotetext{
${ }^{3}$ Internet fraud is commonly referred to as sakawa, but sakawa is a very specific techno-religious mode of fraud that involves spiritual power and that, though very popular nowadays, is beyond the scope of this paper (see Burrell 2012; Warner 2011; Oduro-Frimpong 2014).

${ }^{4}$ Zongo is a common term in Hausaphone West Africa that refers to a temporary settlement of Hausa-speaking Muslims (Schildkrout 1978). Some say that it was originally written as zango and literally means 'station' or 'stranger quarters' (Bari 2014: 379). Most urban towns in Ghana have a zongo where newly arrived inhabitants, usually Muslims, can settle.

${ }^{5}$ The 2010 Ghana Population Census estimated a high unemployment rate of about 37 per cent in East Ayawaso Constituency (Nima) (Ghana Statistical Service 2012; see also CHF International 2010).
} 


\section{Friendship as a form of urban relatedness in the zongo}

Nima experienced a first demographic explosion in the 1940s, with the rapid expansion of Accra and the arrival of new Muslim migrants from all over West Africa who were drawn to the area, as it was close to the market (Owusu et al. 2008; Bari 2014). In the following years more migrants arrived, counting on the hospitality and help of ethnic allies within Nima's huge Muslim community, as they had no direct kin in Accra they could rely on. After both World Wars, veterans were housed around the presidential palace, and many of them were also drawn to neighbouring Nima because of its lively and popular atmosphere. Within a few decades, Nima had been transformed into a densely populated area. New forms of relatedness such as friendship (abokantaka in Hausa) and loyalty sprung up between people living in close proximity. People enjoyed sitting outside together, playing music and dancing to entertain themselves. At the same time, benches were used to discuss the political situation of the country. While the Gold Coast was getting ready to become a new nation state under Kwame Nkrumah, in the alleys of Nima politics was being discussed, political alliances were forged, and one's presence on the benches not only became a mode of entertainment and information sharing but could also turn into a political engagement, or form the basis of a party politics. Football was another binding force that brought neighbours and friends together in bases, and many a football team was founded in the 'crib' of a base.

Today, a base is still a very popular notion in the zongo and refers to a meeting place of friends. Usually it consists of only a few wooden benches placed on a cemented platform in a semi-public alley against the wall of a house. The notion of the base came into fashion during the musical nights of the 1940s, and, according to some, it was borrowed from the military language of Ghanaian World War Two veterans.

The neighbourhood of Nima is ethnically very heterogeneous as its inhabitants have roots all over West Africa. Initially, when Nima was still in its embryonic state, ethnicity played out between the original landlords (the Ga families) ${ }^{6}$ and the 'strangers' - the Muslims who were considered aliens in Ga land. For newly arrived strangers, ethnic affiliation and relations of ethnic loyalty were dominant social forms in the zongos but they cut across neighbourhoods, in ways similar to those that Schildkrout (1978) describes for the Kumasi zongo in the 1970s. Schildkrout notes that friendship and neighbourliness were already emerging as forms of sociality at the time: 'relationships between neighbors may become very close, indeed. They may exchange children for fostering or hire rooms in each other's houses for members of their families' (ibid:: 103). Today, ethnic ties have loosened as second- and third-generation migrants no longer primarily relate to each other along ethnic lines; rather, they identify with those with whom they share houses and alleys, or with those who are the same age and live nearby. With these proximate friends they share leisure time, worries and cares, and happy events as well as setbacks and losses. Kinship, however,

\footnotetext{
${ }^{6} \mathrm{The} \mathrm{Ga}$ are one of the ethnic groups of Ghana and are part of the Ga-Adangme group that mainly inhabits the coastal areas, the Eastern Region and the Volta Region. The Ga are the original inhabitants of Greater Accra.
} 
remains a crucial line of connection; although sometimes it is experienced as a burden from which one can escape by migrating to the city, it continues to define loyalties that cut across an area such as Nima. More generally, notions of friendship strongly resonate with notions of kinship. Friendship and kinship are complementary forms of relatedness (Carsten 2000), although, among the younger generations, friendship predominantly defines conviviality and an ethos of sharing, trust and care, as exemplified in the plurality of bases and formal or semi-formal associations.

Bases usually consist of male friends of the same generation, although an occasional visitor or passer-by, a relative or friend of a base member might join the conversation from time to time. A base is founded when its name is coined. The name will often be painted on a wall next to the base, as a statement of territorialization, and as a claim to this particular part of the public space.

Every day, base members come together to chat, joke, play draughts or the popular Ghanaian card game 'spar', to sleep or relax. Every topic of conversation is touched upon: football, politics, travel, the community, sanitation, corruption, poverty and other social concerns. Friendship and solidarity cement the foundation of a base, and bases shape the zongo's new networks of relatedness. As Issaka explained: 'We are all brothers. We are one family. The reason for me to be in a base is togetherness.' 7

Nima's bases have much in common with the conversation groups of young men in Niger, called fada, which take place around tea-making rituals and which are vividly described and analysed by Adeline Masquelier (2013) in terms of 'masculine waiting culture'; these tea circles are called grins de the in Burkina Faso and Mali (Kieffer 2006).

Bases mainly thrive on dreams that all young men cherish and share. Names of bases such as Chicago, Boston, Brooklyn, Michigan and Alshigar Yankee (literally 'I will enter Yankee', meaning 'I will go to the US') powerfully express a longing for the US as a dream destination. Leaving Ghana and travelling to the US (or Europe) occupies the minds of Nima's youth and is a common topic of conversation.

In this way, bases are windows onto a wider world. Initially, they connected the youth of Nima to the nation state and its new political horizon. Later on they became windows onto places beyond Ghana's national boundaries, to the Western world and a better life. Nima's sitting spots thus act as screens on which imaginaries are projected about various elsewheres, but at the same time bases form the real starting point for actual travels. In some bases contributions are made to finance and organize the travel of a selected base member, with the implicit expectation that once this chosen one has made it to the West, he will support others to join him. The boys of one base, for example, collected money for their brother to travel to the US. However, once he made it to the Promised

\footnotetext{
${ }^{7}$ All names of informants - with the exception of formal representatives - have been replaced by pseudonyms.

${ }^{8}$ The word fada is occasionally used in Nima as well, especially in those bases where the members originate from Niger. These bases are also called ataia or 'tea' bases, as the conversations there are known to be organized around a tea ritual (see Masquelier 2013 for a more detailed analysis of the role and meaning of preparing tea in the fada of Dogondoutchi in Niger).
} 
Land, 'he forgot about us in Nima here', the boys told me. The dream, however, is not relinquished. ${ }^{9}$

Bases are nuclei of unconditional loyalty and care among age-mates, based on proximity and on living in the same neighbourhood, sometimes sharing the same house. These bonds replace kin-based and ethnic relations as the primary relations of loyalty in a context of migration and strangerhood that is typical in zongo communities such as Nima. Moreover, ethnic 'brothers' cannot be friends as they 'know [one another's] homeland' (Meier 2004: 50), which means that ethnic relations hinder friendship rather than facilitate it. Knowing one's homeland refers to being ethnically linked (either distantly or closely) and thus being able to forward gossip to relatives at home. In that sense, non-ethnic allies are better friends as they cannot cause such harm to the migrant's reputation at home. Several young men explained to me how they do not trust kin when it comes to sharing and redistribution, as kin are hierarchically organized, and this inevitably leads to unequal claims and privileges. Relatives do not shun deceit either. Investing in non-kin as friends is crucial and leads to socially more rewarding, and more horizontal, relations of trust, thereby strengthening and broadening one's range of possibilities within the harsh conditions that characterize life in the alleys of Nima. 'You cannot trust people but you have to live together. Friendship is far more important than money,' said Issaka. As Meinert notes with regard to social life in post-war Uganda, trust is 'a struggle, a tricky but necessary moral project and a willed action' (2015: 132). Trust becomes crucial in conditions of uncertainty and indeterminacy, and it often unfolds through experiences of distrust and doubt (ibid.: 133). Investing in trustful relations may also lead to a more hopeful negotiation of a different future, as will be described below.

Ultimately, friendship structures daily interactions and claims on shared public and private spaces, and as such it shapes 'networks of support, trust and empowerment' (see Gratz 2004: 113, for a discussion of artisanal miners' lives in northern Benin). Friends help one another in times of misfortune and loss, such as during sickness, or when a death occurs; they share food, networks, (informal) jobs or information about jobs; they also share rooms, cars, motorbikes, music and computers; they celebrate together all the pleasant events and transitions, such as birthdays, marriage, births and graduation; and they share grief and misfortune. In the public space, friends not only identify with a particular spot, their base, and with the designated name of that base; they also refer to each other as brothers and comply with principles of confidentiality and camaraderie that include moral obligations towards each other. Base brotherhood even extends into lines of (imagined) classificatory kinship relations, as a 'brother' not only considers a friend's close relative as his own, but also uses a vocabulary of kinship to refer to a friend's kin as 'mother', 'sister', 'son', and so on, implying similar interpersonal relationships and social codes of care and respect.

These semantic reproductions of kin relations play a conciliatory role in the absence of extended kin bonds within a situation of extreme heterogeneity. But friendship is, of course, a double-edged sword. As among kin, the thick bonds

\footnotetext{
${ }^{9}$ Similarly, Masquelier (2013) describes how in the fada in a Hausa-speaking part of Niger, young men, while discussing and preparing tea, carve out new futures for themselves in a context of crisis and boredom.
} 
of friendship can be shaded by deception, manoeuvring, quarrels (over money, women or insults) and betrayal, while aspirations and upward social mobility can put pressure on feelings of trust and solidarity, and can compromise unrestricted loyalty. Young men who climb the social ladder - by obtaining better jobs or by marrying or migrating - can find it impossible to continue living in Nima as the appeals for support become too heavy a burden. The fluid constructions of friendship, however, sometimes persist and one's travel or mobility does not necessarily erode resilient base bonds.

\section{'U2canfly': a geography of dreams}

Every area in Nima, however small, has various bases, sometimes occupying the same alley or gutter, but never in the same spot or bench. Neighbourhoods are named after renowned and popular bases, sometimes long after the base's lifespan. Mapping the genealogy of some of the names reveals a particular home-grown history of the area and shows the dreams, hopes and pursuits of the youth at various times.

For those who do not achieve their dreams by travelling abroad, a base serves as a kind of retreat where they can put their life on hold and dream about elsewheres. As such, it enables them to nourish their desires and to continue life in the tough and arduous conditions of the everyday. Mohammed, a member of a popular Nima base, commented: 'How could we cope with these circumstances if we could not sit together here [in the base] to joke and make fun of the hardships of life?' Their common mode of communication - joking - also provides routes of escape from and ways of dealing with everyday life. A base is a place of comradeship and resilient bonds, a place where one can give voice to difficulties and distress, and hence make one's living conditions tolerable. As is expressed by the name of one base, Yenpaba, which literally means 'we don't give up on hope', bases are spaces of hope and of dreams of a better future, in Nima or elsewhere.

The lexicon of bases illustrates the dreams of youth, as is also exemplified in the name of the base U2canfly. One of the base members explained the name's etymology:

Someone from our area had a contact in the American Embassy and he got visas for many of us who then travelled to the US. In those days [the 1980s, the base was founded in 1984] Europe and the US were representing golden opportunities and many boys really moved to these destinations. Our base name inspires everyone to 'fly', to go away, to spread wings.

However, not everyone envisages travelling far away from Nima. Many people hope to acquire their own house, something that has become impossible in the densely crowded area of Nima, but which is still affordable on the outskirts of the expensive city of Accra. Staying in Accra does not mean giving up on transatlantic aspirations. Many of the youth invest in searching for real contacts abroad (with friends who have travelled, or with visitors from outside Ghana) and also for virtual contacts through the internet.

In the following section I elaborate on a specific kind of activity that has taken root in some particular groups of friends, and that has spread like a virus throughout Nima at an incredibly fast pace: browsing and online friendship. 


\section{Browsers, game boys and online friendship}

If you want a big bag a [of] money then,

a Nima mi seh [I say Nima]

Range Rover and Camry [a Toyota car],

a Nima mi seh

Ghetto youth money maker,

a Nima mi seh

Every time when we roll out [go out/have fun],

a Nima mi seh

Where the shatta [men who make big money] dem dey a lot [are many],

a Nima mi seh

Every ghetto youth dem all say [all the ghetto youth say],

a Nima mi seh. ${ }^{10}$

\section{Browsers}

The busiest spaces in Nima - apart from the various mosques at prayer time - are the many cybercafés (Burrell 2012). Every day they are packed with youth, from schoolboys (and to a lesser extent schoolgirls) to young men (and some young women). The big and more popular ones have at least fifteen computers, a relatively fast network, printing services, air conditioning and a generator. Some boys spend their days - or rather their nights - at the café, as it is popularly termed. At night, when life comes to a standstill in the whole of the town, behind the often darkened windows and doors, ticking and clicking continues, as that is the time when the US is online.

Today it is primarily young men who use the cafés, as $3 \mathrm{G}$ on smartphones and modems and domestic Wi-Fi keep the more grown-up consumers at home. A frequent visitor, Ali, estimates that 70 per cent of his age-mates (nineteen years) in Nima use the cybercafé because it is faster and cheaper. Ali and his two friends regularly visit the cybercafé: 'Browsing on your phone is slow and expensive and you can easily be traced if you visit banned sites. We prefer to go to the café together, so we can browse together.'

Compared with the 1990s and 2000s, when cybercafés mushroomed in Accra and Nima (Burrell 2012), the number of cafés has now decreased, although the remaining ones continue to be as crowded and busy as always. The cafés are where the very young ones meet, and where they share hopes and dreams about their futures. In this way, the cafés replace the older meeting places; some youngsters even call their favourite cybercafé their 'base', thereby adding to the moral collapse of the meaning of 'bases' mentioned by various informants who consider today's bases as places where lazy youth kill time while smoking cannabis and engaging in criminal activities. Dreaming in these new locations has a more virtual dimension, since many imagined futures are within reach in a few mouse clicks.

Online friendship is much sought after in Nima, for it is considered a way of making 'quick and easy money', as many of my interlocutors explained. Young men surf and scan the internet hoping to meet someone online with whom they

\footnotetext{
${ }^{10}$ 'Nima mi Seh’, a song by Shatta Wale. Original lyrics in pidgin English.
} 
can establish a durable online relationship. Ideally, one finds a 'friend' who is in Europe, the US or Canada, locations that seem to guarantee the friend's financial power. Numerous rumours travel around Nima about young boys who are buying land, building houses and driving expensive cars thanks to the money given to them by their online foreign friends. The ways in which these friends are urged to donate, however, are not always transparent or straightforward. As we will see, the emotions of the foreign friends are manipulated through stories that elicit pity or that explicitly pressurize moral obligations, something that the boys would never do with their real friends.

\section{Game boys}

While boys who spend their days in cybercafés or online are commonly called browsers, successful browsers are referred to as game boys; however, the distinction is not very clear, as the nomination also depends on the age group and the area of Nima in which they live.

Among their peers, being a game boy is considered an achievement, something to be proud of. Ibrahim, who is an aspiring game boy himself, explained:

A game boy is someone who is into the game. It is very difficult to stay out of the game. Game boys dress and talk in particular ways; they like to show off and to bluff. They wear expensive designer clothes, fancy shoes, jewels such as rings and chains, and they use iPhones. They copy famous musicians such as Shatta Wale and Sarkodie. They spend and blow money in a way that will make you know that they are game boys: for example, they celebrate the birthday of their car, they throw pricey parties.

In his book on Ivorian young men, Newell (2012) describes the bluffeurs, who 'bluff' in similar ways and pretend to be successful by spending money that they have gained in illicit ways, and in turn - paradoxically - they become successful and rich. ${ }^{11}$

Game boys hang around in small cliques of three to five and visit the cybercafés or each other's homes in groups. Surfing the web needs to be done in groups; browsing together is informative and the younger ones are keen to learn the tricks of the trade from more experienced browsers. In the evenings and at night, the popular cafés are filled with young boys who swarm around the screens, hoping to find avenues to make life more bearable through monetary gains. A few girls also hang around in the cafés, but most of the girls just visit their Facebook pages or mailboxes, although there are some striking exceptions, as we will see below.

\section{Boys who are girls: online transnational transgendered relations}

The most popular and successful spaces in which to make contacts with potential friends are dating sites. Getting in touch with someone who is looking for love is

\footnotetext{
${ }^{11}$ The game boys or browsers have similarities with the Cameroonian feymen as described by Malaquais (2001) and Ndjio (2008); the latter states that 'feymen are the iconic figures of the new modalities of wealth creation', the result of a successful monetary quest through 'the economy of fraud, swindle and deception' (ibid.: 271).
} 
known to have the potential to lead to a financially rewarding relationship, and this is what most boys are looking for.

It is commonly known that the easy targets are white men and women, often lonely or single, who subscribe to dating sites in search of love or (virtual) company. To get in touch with the men, game boys pretend to be girls. They construct fake profiles by using pictures of girls, either of existing girls they know (friends or girlfriends, or friends' girlfriends), or online pictures that are copied and pasted from websites or bought online. Once a contact is established, much depends on the social skills of a browser to convince the white man of his trustworthy and genuine intentions. As Bashir explained:

You have to go slowly and take your time. Sometimes you chat for months in friendly ways. Once you have got a bite, you have to know how to chat with your contact to make him feel comfortable with you. You have to know how to read the mind of the white man and that demands experience and a thorough study of the man's profile.

White men and women - mostly single and middle-aged - are easy prey for browsers, and the skill is to have enough flair to keep someone dangling once he has 'bitten', to use the browsers' jargon. The ultimate aim is to receive money from the contact - money that is sent out of love or compassion. Contacts are aptly called paypals, a term that has become very common in Nima's backstreets. A paypal is someone with whom you have a long-term relationship, with whom you regularly chat, and who sends you money. Ibrahim explained the etymology of the word 'paypal': 'Those in Europe and the US we were writing letters to when we were small boys were our penpals. Now we write emails and we chat through Messenger with paypals, because we hope to receive some cash from them.'

The fictitious profiles usually display pictures of white girls, 'because American men don't want black women, they want white girls or half-half'. Browsers search on the net for pictures of porn star-like beauties who are supposed to charm the lonely white man in search of love. Some specific websites sell series of photographs of the same girl in different poses, some less erotic and some more so, and it is even possible to buy video footage of the girl in various positions. The profile needs to explain the fact that the girl is living in Ghana but is white (or 'half-half'), and so very often girls are presented as being volunteers, expats or NGO workers living in Accra but originally from the US, or daughters of expats who live in Ghana. Others are introduced as having a Ghanaian father and a white mother or vice versa. The more experienced its creator, the more detail goes into preparing the profile in order to anticipate any imaginable situation or question from the paypal.

A browser has to ensure that he identifies with his role as a girl and writes 'girlish' chat to his paypal to keep the latter interested and flattered. However, after a while many paypals demand a Skype or WhatsApp call, which encourages the browser to be creative and find a suitable, real substitute for the profile picture. It is during this phase that girlfriends, or friends of friends, can play an active role in lending their voice - obviously in exchange for a part of the profits. Girls such as Hawa (who appeared at the start of this article) take care of telephone and Skype calls and sometimes - almost inevitably - also do part of the chatting, once their numbers are known to the paypal. Hawa, for example, has three phones and 
receives calls on them from her own friends and from different paypals almost daily. She works for a few friends who are knowledgeable and skilled in the online friendship business. She reserves one phone for her daily Ghanaian contacts, while the other two are used for her online chatting with paypals abroad. She is a good-looking, smart and well-dressed woman in her late twenties, quite fluent in English and skilled at (partially) hiding her Ghanaian accent. Most people in the house know about her activities and some explicitly condemn them, but they feel powerless in preventing her from continuing her work. When the browsers need Hawa, they never enter the house; rather, they call her to meet in the dark alleys outside the main gate. She explained the division of work to me as follows: the boys create the profile, look for the contact and do the chatting, for a few weeks or months. As soon as the paypal asks to make a call, the browsers call on Hawa's services and start using her phone number. A large Samsung smartphone was given to her by the leader of the browsers. She gets to keep this phone and, in addition, she normally takes a share of 20 per cent of the profits. Some boys commission their own girlfriends to make the calls for them. Engaging a girl in browsing work requires a firm basis of trust, as the browser needs to share the paypal's phone or WhatsApp details with the girl. One informant explained how these girls are often school dropouts. In Nima, stories abound about girls who deceive their boyfriends or friends by nurturing relationships with paypals behind their backs, cashing their money and sometimes even eloping with the paypal.

The whole setup of online friendship serves several goals, but the main one for the browsers is to receive cash from the paypal, usually through money transfer companies such as Western Union or MoneyGram. Some might use the friendship to extend networks beyond Africa, or they may hope to get an invitation and the necessary papers to migrate, but most browsers are primarily interested in receiving cash, and any means of achieving this goal is acceptable. When someone receives money from their 'client', it is said that they have 'hit'. 'Hitting' is a very common term in Nima and beyond to refer to obtaining money through a transfer.

Browsers never reveal the details of their fake profiles, such as the login name and password. They also restrict the information they share with their "phone girls' to specific Skype, WhatsApp or Messenger details. Browsers and their assistants depend on one another in order to maintain the relationship with the paypal, and thus share the same ambition of reaping as much money as possible from the contact. This joint ambition cements the illicit bond, even though some girls deceive their accomplices and run away with the paypal and his money. If a browser does not have a girl to make the calls for him, other browsers say that 'he hasn't got a phone'.

\section{Cyber masters and unworldly boys in an online world of trickery}

The complex socio-psychological aspects of online friendship and fraud require browsers as well as their 'phone girls' to have the necessary knack and instinct to keep in control of the game. In the same way as one needs to be streetwise to survive in a rough urban environment such as Nima, one needs to be cyber-wise and have a shrewd alertness to remain in control of the online performance. 
Beginners make mistakes that can cause possible clients to slip off the hook. Therefore, it is important for them to learn how to be cyber-wise from experienced browsers. Usually, young boys visit cafés together and try to learn from the more experienced and successful browsers, meanwhile evading the curious gazes of other visitors to the café (see also Burrell 2012 on how youth in Accra use internet cafés). One shares screens only with friends or masters. A master with a strong reputation who has been able to reel in an impressive catch is called a hitter or a baron (in reference to the big drug dealers, who are also called barons) and is admired for his skilfulness. Being a baron means having acquired wealth quickly, and this wealth is displayed in the way he consumes, dresses and lives.

The biggest barons usually move out of Nima, in order to avoid social pressure and the expectation of redistribution to friends, kinsmen and followers (for a similar observation among Nigerian 419 men or scammers, see Smith 2001). When they move, they keep their new address secret, but take along their boys to assist them in their browsing activities. Meanwhile, the boys enjoy the privilege of the baron's shared knowledge and his luxury environment. Boys learn the tricks of the trade by watching a master at work. Sometimes, though, the boys are more cyber-wise than the master, but they depend on him financially and materially for browsing time, modems, laptops and a safe place to work. A beginner is called a boy or a maid. He starts his cyber career by carrying out petty jobs for his master, such as searching for profile pictures, buying false IP addresses, ${ }^{12}$ or doing small chatting jobs in the margins of the larger enterprise.

Boys often live with their master and are supposed to serve the baron by doing all kinds of non-browsing-related trivial jobs, such as buying food for the group, taking messages to colleagues, buying phone credit and cigarettes, sweeping the house, or looking for wires, cameras and other equipment. The hierarchical relationship between barons and boys can be upset when boys become more skilful and smarter than their masters, or when they start to steal clients or critical cyber information from them.

Masters spot the boys in the cybercafés and try to recruit those who are smart and cyber-wise. Getting in touch with a master may also happen through friends, usually from one's base. Browsing is very much a collective activity that boys and young men engage in together. They visit the cybercafé together and often share one computer (Burrell 2012). Therefore, group browsing needs to be firmly based on confidentiality and trust, things that the bases offer, although the financial stakes sometimes push relations of friendship to their limits. Networks are crucial in browsing activities and in acquiring browsing skills. Friends share knowledge and tricks, they share rooms and profits, and they even share phone girls and paypals.

\section{'U2 can browse': online and real-time friendship}

Not all online friendship is about deceit and luring money out of (online) friends' pockets. Browsing is also an act of being connected and being global. Young men

\footnotetext{
${ }^{12}$ Ghanaian IP addresses are banned from many of the American and European dating sites, precisely because of Ghanaian internet users' reputation for being fraudulent (Zook 2007 discusses this in relation to 419 networks in Nigeria).
} 
who have friends abroad have networks that extend as far as their dream destinations such as the US and Canada. Youth in Nima are connected with other parts of the world and are therefore virtual cosmopolitans. However, being global depends on local connections, on being locally attached: it is through trustworthy friends at home that one acquires cyber credibility and - paradoxically - becomes a wizard in treachery and trickery. In other words, the world wide webs of urban youth in Nima are rooted in local friendship bases; being locally grounded in webs of confidentiality helps one become cosmopolitan.

Browsing is democratic: any young boy or girl can acquire the skills and go online, assuming that they have friends who will show them how. As such, urban Accra offers enormous possibilities and opens up new ways and opportunities to make quick money and fast wealth. Online love and friendship can occasionally lead to actual travel, but it primarily opens up new possibilities to survive in the difficult conditions that characterize a place such as Nima. Browsing can give one (increased) financial power, it can elevate one's reputation and esteem, it can lead to a new lifestyle and social mobility, but essentially it can give one a sense of being in control in a world in which one's place is otherwise defined by marginalization, deprivation, exclusion or unequal access to resources. Conversely, the fast wealth accumulated through online fraud can invert hierarchical relations and propel young conmen into celebrity-like popular figures with a much envied and admired lavish lifestyle. In this sense, too, online fraud is democratic: in theory, every boy or girl who has a few Ghanaian cedis and who is ready to learn how to browse can aspire to live the life of a star (Burrell 2012).

Some game boys and phone girls explain browsing as a kind of retaliation. It represents 'payback time' for decades of colonization and exploitation. This is a much heard, but equally often criticized, common discourse justifying online criminal activities: 'The whites have enslaved us, they have stolen all our resources, they have exploited us and now the tables are turned. We take back our share,' said Aisha. This argument, however, is morally repudiated by many as 'cheap and easy' and unjust.

\section{Takaashi in a changing moral economy}

Cyber fraud in Ghana is still on the rise and some claim that it has become a nationwide phenomenon. ${ }^{13}$ Among the youth in Nima, searching for online friends through dating sites is currently the most popular option within the underground economy. The risks are limited, the chances of being tracked are minimal, and the wrongdoing is considered relatively minor. As a kind of 'lesser evil' it is even used as a front for other criminal activities. Some robbers and drug dealers pretend to be browsing to cover up for the sudden upgrade in their lifestyle. Those involved in deception with the help of spiritual powers (sakawa) also pretend to be browsers so as not to be suspected of other fraudulent activities. Jalil, a browser, stated that:

\footnotetext{
${ }^{13}$ 'Cyber crime: Ghana 2nd in Africa, 7th in the world', MyJoy online, 1 August $2013<$ https:// www.ghanaweb.com/GhanaHomePage/NewsArchive/Cyber-crime-Ghana-2nd-in-Africa-7th-inthe-world-281095>, accessed 22 January 2018.
} 
If you are born and raised in the zongo, you will not find yourself in a good condition. If you don't take time you will find yourself in drug dealing, robbery and prostitution, so you have to find another way of taking care of yourself [i.e. browsing].

The offices of Western Union and MoneyGram in Nima reportedly have the highest financial turnover in Ghana, together with those in Madina, another zongo in Accra. This was confirmed to me by Western Union managers in Nima (at Access Bank), although it was impossible to obtain figures. Overall, adults in Nima take an ambiguous stance vis-à-vis browsing. On the one hand, Avalon, the leader of a vigilante group in Nima that tries to fight various kinds of crime, lamented that 'we lost 50 per cent of our youth through cybercrime'. Thus, people condemn online fraud and theft and fraudsters are reproached for being lazy, idle, greedy, spoiled and immoral. On the other hand, cyber fraud has taken theft and robbery from the streets of Nima to the virtual world - or at least the world outside Nima. 'Many of the guys are non-educated, but they know how to browse and deceive the white!' shouted Jabila, the landlord of a large house in Nima, almost with pride. Although it is publicly condemned and combatted in radio programmes, cyber fraud has generated a greater circulation of money in Nima and a higher financial capacity among youth, and, as some claim, it has occasioned a decrease in armed robbery and theft.

However, the creation of 'new social spaces that transcend national boundaries' (Zook 2007) has in turn redefined local relations and the moral economy among youth in Nima. New worlds and prospects have opened up through the internet, and competition has driven a wedge between many friends. The desire for - and proximity of - conspicuous consumption has changed people's 'moral fibre' in more intimate and profound ways than the online trickery in itself. Online fraud can generate fast wealth, but the successful browser today keeps this wealth to himself and shares only with his assistants, if he shares at all. Older forms of redistribution whereby riches however modest - are shared with kinsmen and friends and according to patronclient relations have altered drastically. Redistribution is now often limited to a small circle of girl- or boyfriends, helpers and accomplices. Daniel Jordan Smith has described similar processes in Nigeria, where 419 scamming has altered relations of power and inequalities in ways that are publicly condemned, 'specifically in the increasingly individualized character of greed, corruption and aspirations of power' (2001: 821). Ndjio discusses comparable reactions to the fast wealth of feymen in Cameroon in what he calls the 'economy of retention' (2008: 288). As explained above, once they are materially successful, browsers move out to escape expectations of redistribution. Conspicuous consumption as a form of 'bluffing' has encouraged greed and selfishness, thereby destroying former mechanisms of loyalty and friendship.

Many youths complain of this change in morality, especially among friends, as the following quotes demonstrate:

Now a brother can come and lie to you!

It has become very difficult to survive genuinely. In those days [referring to about ten years ago] it was hassling, but it was genuine hassling, but nowadays our society is disintegrating.

If someone gives you to eat, eat. Don't ask where it came from. There is less trust today there are opportunities, but there is too much takaashi. 
Takaashi is a Hausa word that means 'to hit someone by foot', or 'to step on others to become big', 'to take advantage of others in order to grow'.14 Takaashi was mentioned by several adults and youths when discussing morality and friendship. Online fraud has adulterated real-time trust, the online stakes have become too high, and cyber information has become too sensitive in intensely competitive spaces such as the virtual world. Stepping on others is a way to grow, to escape the zongo and to reinvent oneself.

Takaashi drives successful browsers away from Nima to the new neighbourhoods on the outskirts of Accra, where they can dodge mechanisms of redistribution and expectations of sharing. These transformational dynamics of sharing are obviously not restricted to the zongo, or to online friendship and fraud. Several authors have written about similar transformations of the moral economy that have been partially initiated by new figures in the youth culture of other parts of Ghana and West Africa; these include Newell (2012) on bluffeurs in Côte d'Ivoire, Ndjio (2008) on feymen in Cameroon, and Smith (2001) on 419 conmen in Nigeria. Similarly, in the Ghanaian zongo, sharing with friends and kinsmen is 'our mentality', as Mohammed put it; one is expected to apportion any acquired wealth with one's immediate allies - and especially with friends. Redistribution, while being expected and almost inescapable, raises an individual's status and esteem in the zongo. Failure to comply with this expectation is denounced publicly.

\section{Conclusion}

The world wide web has given youths the chance to achieve agency and to 'world' themselves - 'to participate in an emerging, albeit limited, configuration of "world level" transactions that emerge from the initiatives of Africans themselves' (Simone 2001: 26). Meanwhile, the social fibre of solidarity, generosity and mutual trust seems to have dissolved in a more individualistic, competitive and antagonistic world, thereby altering relations of power, redistribution and inequality in favour of the cyber-wise few, and possibly turning relations of trust into distrust and deception.

Browsers' and phone girls' relationships are characterized by ambivalence and uncertainty. The girls are initially dependent on the boys for access to information about possible clients and to the clients themselves, but gradually they take control as the embodiment of the paypals' longing and love, thereby making the browsers dependent on their skills, their willingness to be involved and, especially, their trustworthiness. Only those who master a sophisticated degree of artistry as conmen succeed in keeping control of these ambivalent relations of dependency and thereby enjoy recognition and fame. The phone girls in their concealed, ingenious and agile ways not only turn global hierarchies upside down, but also redefine gender relations between zongo boys and zongo girls.

The phone girls, as handmaidens of the browsers, fool their American lovers, who live in a distant world that is out of reach but so much desired, as is

\footnotetext{
${ }^{14}$ These translations were provided by Baba, an opinion leader in Nima.
} 
epitomized by the names of many bases and by the outfits and accessories of youth in Nima. They thereby take advantage of the longing for love and attachment of the lonely white males to feed their own desire for wealth and esteem, and by establishing very ambivalent relationships with their paypals in the process. While they mock the foolishness and persistence of their virtual lovers, they make themselves financially dependent on the money that their lovers send, materially mirroring the affective dependency of the men.

One wonders whether these lovers are a new category of sugar daddy with whom boys and girls try to establish relations of transactional but virtual 'love', just as they do with wealthy and elderly men at home (Dinan 1983; Mazzocchetti 2009). As such, these online lovers can be situated in a realm of commoditized, ambivalent alliances that is an extension of locally existing modes of relatedness. It is notable that the money obtained through the hoodwinking activities of browsers and girls is no longer used to physically travel to dream destinations such as the US. Rather, many boys and girls prefer to remain in Ghana and upgrade their living conditions by moving out of Nima to selfcontained houses, or to boost their local status and esteem by adopting new styles of dress and by engaging in the conspicuous consumption of blingbling and fancy goods. Their new fame is established and recognized by 'staying in town and showing off', as many interlocutors explained, instead of migrating abroad and returning home, which is what zongo boys used to dream of and many of them used to do.

Going back to the various modalities of friendship in the zongos, we can conclude that online love or relationships rely on strong local bonds of trust and friendship, among boys as well as between boys and girls. Boys or young men browse together, thus pooling their skills while teaching one another how to hit or find a potential online 'friend'. Later, boys rely on girl friends - or girlfriends - to make the phone calls and in some cases take over chatting with paypals.

Acts of deception and fraud are thus paradoxically grounded in relations of ambivalent 'tricky' trust (cf. Meinert 2015) among friends in the neighbourhood. At the same time, browsing activities morally defy the foundations of trust and loyalty because of the wealth and external possibilities that the fraudulent activities smuggle into the local social world. Takaashi - or 'stepping on others' to enrich oneself, as it is aptly called in the backstreets of Nima - stirs up distrust and socially isolates individuals, while that distrust in turn opens up possibilities for social upward mobility or for leaving Ghana.

Friendship among age-mates, as an urban form of kinship in an extremely heterogeneous setting such as the zongo, generates hope and new possibilities, if only by putting life on hold while dreaming together of a better life elsewhere.

Online friends (paypals) across the ocean are not only trapped by the joined forces of friends and their webs of deception in the virtual world; we can assume that paypals themselves are also tricked by mechanisms of self-deception as a way of dealing with the highly uncertain and untrustworthy context of the internet. Online relations are particularly ambiguous as they allow for fake and constructed identities, and this paradoxically leads to the development of trust, which, in principle, is beyond the control of the individual (Pedersen and Liisberg 2015). In summary, friendship builds on, and in turn generates, trust, which may then lead to the formulation of hope for a fundamentally different future, even though the people involved are also acutely aware that such hope 
may be disappointed or betrayed in the end. A friend may also disappoint, for example by starting a new life elsewhere without acknowledging the support of the former friends he has left behind or reaching out to them from his new station in life. Nonetheless, some of these greedy and successful browsers are envied, which is yet another form of recognition by their friends.

I have shown how friendship and kinship can be considered as different but complementary layers of relationships, but how friendship is more malleable and may entail more genuine relations of trust, which are more easily achieved through social processes of reciprocity, support and loyalty than in classic kinbased relationships. An urban migratory context provides a good pretext to get away from the burden of kinship and the normative relations and claims kinship relations imply.

\section{Acknowledgements}

The text was first presented at the 'Writeshop on Urban Kinship' in Cape Town in December 2015. I am grateful to the organizers, Mats Utas and Jesper Bjarnesen, and all the participants of the workshop for their valuable comments on the text. Many thanks also go to Filip De Boeck and Olaf Zenker for their feedback on earlier drafts. Finally, I am grateful to the young men and women I have worked and lived with in Nima, to the family of Aya Maryam Salifu and to my interpreter Baba Musah Pachaka.

\section{References}

Agyei-Mensah, S. and G. Owusu (2012) 'Ethnic residential clusters in Nima, Ghana', Urban Forum 23: 133-49.

Bari, S. O. (2014) A Comprehensive History of Muslims and Religion in Ghana. Volume 1. Accra: Dezine Focus.

Burrell, J. (2012) Invisible Users: youth in the internet cafés in urban Ghana. Cambridge MA: MIT Press.

Carsten, J. (ed.) (2000) Cultures of Relatedness: new approaches to the study of kinship. Cambridge: Cambridge University Press.

CHF International (2010) Accra Poverty Map: a guide to urban poverty reduction. Accra: CHF International.

Dinan, C. (1983) 'Sugar daddies and gold diggers: the white-collar single women in Accra' in C. Oppong (ed.), Female and Male in West Africa. London: George Allen and Unwin.

Ghana Statistical Service (2012) 2010 Population and Housing Census: summary report of final results. Accra: Ghana Statistical Service and Sakoa Press $<$ http://www.statsghana.gov.gh/pop_stats.html>, accessed 13 September 2017.

Gratz, T. (2004) 'Friendship ties among young artisanal miners in northern Benin (West Africa)', Africa Spectrum 39 (1): 95-117.

Harvey, M. E. and R. R. Brand (1974) 'The spatial allocation of migrants in Accra', Geographical Review 64 (1): 1-30.

Kieffer, J. (2006) "Les jeunes des "grins" de thé et la campagne électorale à Ouagadougou', Politique Africaine 101: 63-82.

Malaquais, D. (2001) ‘Arts de feyre au Cameroun', Politique Africaine 82: 101-18. 
Masquelier, A. (2013) 'Teatime: boredom and the temporalities of young men in Niger', Africa 83 (3): 385-402.

Mazzocchetti, Y. (2009) Etre étudiant à Ouagadougou: itinérances, imaginaire et précarité. Paris: Karthala.

Meier, B. (2004) 'Nähe und Distanz: freundschaften bei nord-ghanaischen migranten in Accra/Tema', Africa Spectrum 39 (1): 41-62.

Meinert, L. (2015) 'Tricky trust: distrust as a point of departure and trust as a social achievement in Uganda' in S. Liisberg, E. O. Pedersen and A. L. Dalsgard (eds), Anthropology and Philosophy: dialogues on trust and hope. New York NY and Oxford: Berghahn Books.

Ndjio, B. (2008) 'Mokoagne moni: sorcery and new forms of wealth in Cameroon', Past and Present 199 (S3): 271-89.

Newell, S. (2012) The Modernity Bluff: crime, consumption, and citizenship in Côte d'Ivoire. Chicago IL: Chicago University Press.

Oduro-Frimpong, J. (2014) 'Sakawa rituals and cyberfraud in Ghanaian popular video movies', African Studies Review 57: 131-47.

Owusu, G., S. Agyei-Mensah and R. Lund (2008) 'Slums of hope and slums of despair: mobility and livelihoods in Nima, Accra', Norwegian Journal of Geography 62 (3): 180-90.

Pedersen, M. O. and S. Liisberg (2015) 'Introduction: trust and hope' in S. Liisberg, E. O. Pedersen and A. L. Dalsgard (eds), Anthropology and Philosophy: dialogues on trust and hope. New York NY and Oxford: Berghahn Books.

Roy, A. and A. Ong (eds) (2011) Worlding Cities: Asian experiments and the art of being global. Oxford: Wiley-Blackwell.

Schildkrout, E. (1978) People of the Zongo: the transformation of ethnic identities in Ghana. New York NY and London: Cambridge University Press.

Simone, A. (2001) 'On the worlding of African cities', African Studies Review 44 (2): $15-41$.

Smith, D. J. (2001) 'Ritual killing, 419, and fast wealth: inequality and the popular imagination in southeastern Nigeria', American Ethnologist 28 (4): 803-26.

Warner, J. (2011) 'Understanding cyber-crime in Ghana: a view from below', International Journal of Cyber Criminology 5 (1): 736-49.

Zook, M. (2007) 'Your urgent assistance is requested: the intersection of 419 spam and new networks of imagination', Ethics, Place and Environment 10 (1): 65-88.

\begin{abstract}
The young men of Nima, a popular neighbourhood in Accra, organize themselves in small age groups that meet almost daily in a specific spot, to chat, play and 'wait', while dreaming together of a better future in a distant elsewhere. The friendships that find root in these so-called bases, which often have names such as 'Chicago' or 'Brooklyn', lead to hope and specific modes of action through which these young people engage with the city, the wider world and their own aspirations. Taking these bases as an ethnographic vantage point, this article looks into relations of proximity, friendship and trust and the agency of the young men. The article's focus then turns to the virtual world of the same young men - and their girlfriends - in order to analyse the new modes of
\end{abstract}


friendship that are shaped by their internet browsing. It shows how the modalities and intricacies of online, often deceitful, friendship and love rely on vital localized friendship bonds, defined by trust, of browsers in the zongo. Browsing opens up new possibilities but also challenges, and erodes existing moral socialities between friends.

\section{Résumé}

Les jeunes hommes de Nima, un quartier populaire d'Accra (Ghana), s'organisent en petits groupes d'âges qui se réunissent presque tous les jours dans un endroit spécifique pour discuter, jouer et " attendre ", tout en rêvant ensemble d'un futur meilleur dans un ailleurs lointain. Les amitiés qui trouvent racine dans ces bases, comme on les appelle, qui portent souvent des noms comme " Chicago » ou « Brooklyn », mènent à l'espoir et à des modes d'action spécifiques par lesquels ces jeunes appréhendent la ville, le monde autour et leurs propres aspirations. En prenant ces bases comme point de perspective ethnographique, cet article examine les relations de proximité, d'amitié et de confiance, ainsi que l'action de ces jeunes hommes. L'article s'intéresse ensuite au monde virtuel de ces mêmes hommes (et leurs compagnes) pour analyser les nouveaux modes d'amitié qui sont influencés par l'usage qu'ils font de l'Internet. Il montre comment les modalités et les complexités de l'amitié et de l'amour sur Internet, souvent trompeurs, reposent sur des liens d'amitié localisés essentiels, définis par la confiance, des surfeurs Internet du zongo. Internet crée de nouvelles possibilités mais aussi des difficultés, et érode les socialités morales existantes entre amis. 